\title{
Properties of Baby Food Developed from Orange-Fleshed Sweetpotato and Mangoes
}

\author{
Charity N. Muchoki',2, Jasper K. Imungi1 \\ ${ }^{1}$ Department of Food Science, Nutrition and Technology, University of Nairobi, Nairobi, Kenya \\ ${ }^{2}$ Directorate of Research Accreditation and Quality Assurance, National Commission for Science, Technology \\ and Innovation, Nairobi, Kenya \\ Email: charity.muchoki@yahoo.com
}

How to cite this paper: Muchoki, C.N. and Imungi, J.K. (2017) Properties of Baby Food Developed from Orange-Fleshed Sweetpotato and Mangoes. Food and Nutrition Sciences, 8, 979-988.

https://doi.org/10.4236/fns.2017.811070

Received: October 3, 2017

Accepted: November 12, 2017

Published: November 15, 2017

Copyright (C) 2017 by authors and Scientific Research Publishing Inc. This work is licensed under the Creative Commons Attribution International License (CC BY 4.0).

http://creativecommons.org/licenses/by/4.0/

\begin{abstract}
Vitamin A Deficiency (VAD) is a major concern in the world today and is a risk for children in developing countries. Trends have shown that food based interventions are the preferred long-term solution in controlling VAD as opposed to supplements. The orange-fleshed sweetpotato and mangoes are rich in beta-carotene, yet they are not fully utilized. A processed product from these raw materials will make use of surplus produce, promote year round utilization, increase the economic value of the crops and provide variety and convenience of uses. The roots were obtained from the field station, University of Nairobi, while the mangoes were purchased from the local market. The roots were washed, peeled and sliced. They were boiled to softness and mashed. The mangoes were washed, peeled, sliced and pureed in a blender. The two raw materials were mixed using six different formulations. Each formula was pasteurized at $80^{\circ} \mathrm{C}$ for $5 \mathrm{~min}$ in a batch pasteurizer, packaged by hot filling, cooled immediately and stored. The cooking time for the sweetpotatoes was $19.5 \mathrm{~min}$. Losses of beta-carotene and ascorbic acid ranged from $17 \%-21 \%$ and $18 \%-28 \%$ respectively after pasteurization. The total solids increased by $3 \%$ on average. Changes due to storage of the product at $25^{\circ} \mathrm{C}$ could be detected by sensory analysis only after six months of storage. After storage, beta-carotene and ascorbic acid decreased by $18 \%$ and by $45 \%$ respectively. The final stored product could provide $73.7 \%$ and $64.5 \%$ of retinol equivalent for infants and $1-10$ year-olds respectively. It could also provide $48.9 \%$ of ascorbic acid for children 1 - 10 years old, when consumed in amounts of $100 \mathrm{~g}$ per day.
\end{abstract}

\section{Keywords}

Sweetpotato, Mangoes, Baby Food, Beta-Carotene, Ascorbic Acid 


\section{Introduction}

Vitamin A is one of the micronutrients whose deficiency is a major concern in the world today. It is estimated that almost 250 million children in developing countries are at risk, of whom 2.83 million are clinically deficient [1] [2]. Vitamin A deficiency (VAD) is prevalent among the poor proportion of the Kenyan population who constitutes the majority. In a survey done in Kenya, 21.4\% (3 Districts) had moderate VAD and 78.6\% (11 Districts) had severe VAD. The study showed that the children aged 6 - 24 months are at the greatest risk of this deficiency [3]. Food based interventions involving dietary modifications have been found to be the preferred long-term solution in controlling VAD [2] [4].

The sweetpotato can be produced on fairly infertile soils with little input and can withstand periods of irregular rainfall and drought. The mango (Mangiferaindica Linn) is one of the most delicious of all fruits. It is produced principally in the developing countries of the tropics [5], but trade in mango has been limited by the highly perishable nature of this fruit. Both orange-fleshed sweetpotato and mangoes are rich in beta-carotene.

Developing a processed product from these raw materials would decrease losses and make use of surplus produce. Secondly, the product could greatly increase the utilization of sweetpotato, which despite its high nutritional value, is perceived as a poor man's food. This discourages its more widespread use. Thirdly, both sweetpotato and mangoes have poor keeping quality under local (tropical) conditions thus it would promote year-round as opposed to seasonal, consumption. Fourthly, the product would increase the economic value of the crops to the producers and increase the efficiency of the food delivery system thus freeing time for other occupations. Lastly, the product would provide variety and convenience of uses by making a product with characteristics distinct from those of the raw material.

Sweetpotato can be pureed to produce a product that may be used for baby foods, pie fillings, reconstituted potatoes, sweetpotato flakes and numerous other products. One of the major advantages of using puree for processed products is that there are no size or shape criteria for the roots. A high quality puree can be produced from virtually any size or shape of storage roots, thus the entire crop can be utilized. Since an aseptically processed puree can be stored at ambient temperature, there is a minimal storage energy requirement after initial processing. Other advantages include a year-round supply and a substantially reduced product volume for storage. Addition of the juice or pulp of different fruits significantly improves aroma scores [6]. Mango puree may be used to produce beverages, or cereal flakes, baby foods or other dessert preparations.

Pasteurization increases the storage life of foodstuff and minimizes foodborne diseases. Hot-filling of the product, after pasteurization helps in deaeration and commercial sterilization. The removal of oxygen lessens deterioration during storage. 


\section{Materials and Methods}

\subsection{Sweetpotato Roots and Mango Fruits}

Orange-fleshed sweetpotato roots (Hernandez variety) were obtained from Field Station, University of Nairobi, Faculty of Agriculture while ripe mangoes (Mangiferaindica) cultivar Ngowe' were bought from local markets and both were transported to the Department of Food Technology and Nutrition for preparation. The sweetpotato roots were washed, trimmed, peeled and cut into slices approximately $1 \mathrm{~cm}$ thick. The mangoes were washed, peeled and the flesh blended using a hand blender.

\subsection{Determination of Optimal Cooking Time for Sweetpotato}

To determine the optimal cooking time, $200 \mathrm{~g}$ of sweetpotato slices were put in boiling water and cooked to softness. The time required for the slices to cook to softness was measured. The experiment was done in triplicate and the averages recorded.

The cooked sweetpotato slices were mashed to a uniform consistency. The consistency of the sweetpotato mash was adjusted using $50 \%(\mathrm{v} / \mathrm{w})$ water (some of the water used for boiling to avoid great losses of leached nutrients) and $8 \%$ $(\mathrm{w} / \mathrm{w})$ sugar.

\subsection{Baby Food Manufacture}

The baby food was manufactured as per Figure 1 using five different mixes (treatments) of the sweetpotato mash and the mango puree as shown in Table 1.

\subsection{Analyses}

Nutritional analyses were carried out on the raw sweetpotato, the boiled sweetpotato, the mango puree and on the five mixes: Total solids were determined by drying the samples in a hot air oven at $70^{\circ} \mathrm{C}$ for 18 hours to a constant weight [7]. The $\mathrm{pH}$ of the samples was measured on a pH meter (Model $290 \mathrm{Mk} 2 \mathrm{PYE}$ UNICAM) after standardization of the instrument with a buffer solution [8]. Total titratable acidity was determined by weighing the samples and mixing with water then titrating directly. The total titratable acidity was calculated as percentage equivalent of malic acid in mangoes and the mix [7] (Calculation: $1 \mathrm{ml}$

Table 1. Different mixes (treatments) for formulating the baby food.

\begin{tabular}{ccc}
\hline $\begin{array}{c}\text { Samples } \\
\text { (mixes) }\end{array}$ & $\begin{array}{c}\text { Potato mash } \\
\text { (\% weight) }\end{array}$ & $\begin{array}{c}\text { Mango puree } \\
\text { (\% weight })\end{array}$ \\
\hline 1 & 90 & 10 \\
2 & 80 & 20 \\
3 & 70 & 30 \\
4 & 60 & 40 \\
5 & 50 & 50 \\
\hline
\end{tabular}




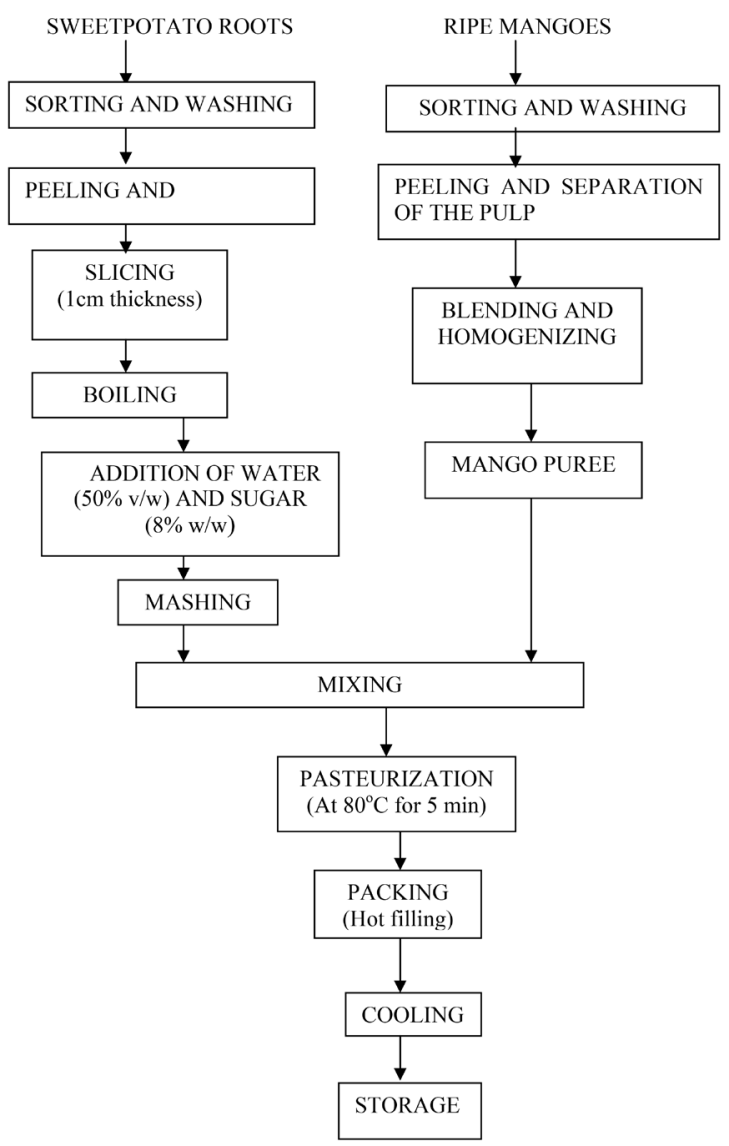

Figure 1. Product manufacture flow diagram.

of $0.1 \mathrm{~N} \mathrm{NaOH}$ represents 0.66 acids per litre, calculated as malic acid). Total soluble solids in Brix were determined using a hand refractometer (Kruss Hand refratometer-Germany) [7]. Beta-carotene was determined using method number 44 of the international Federation of fruit juice [9]. Absorption reading was done using CE 4400/UV VIS Double Beam Scanning Spectrophotometer. Ascorbic acid was determined by titration with standard solution of 2,6-diclorophenol indophenol [10].

The acceptability of the product was determined using a 7-point Hedonic rating scale with an untrained panel, with 7 being 'like very much' and 1 being 'dislike very much'. Four was for 'neither like nor dislike'. The attributes scored were: appearance, flavor, colour, mouthfeel (texture) and overall acceptability.

Total ash, crude protein and crude fiber of the stored product were determined by the method outlined by Pearson [11].

Shelf life was determined using accelerated shelf-life study as follows: The samples were stored in an oven at $55^{\circ} \mathrm{C}$, for 1 day, 2 days, up to 6 days and the duo-trio sensory test was done. Shelf life up to six months was chosen because similar baby foods in the market store for 4 - 8 months. The test was performed on two successive days using 14 panelists. Each day, the panelists were presented with three sets of samples. The three sets had samples stored for different number of days. 
Day 1: Set 1. Storage for 4 days at $55^{\circ} \mathrm{C}$

Set 2. Storage for 1 day at $55^{\circ} \mathrm{C}$

Set 3. Storage for 2 days at $55^{\circ} \mathrm{C}$

Day 2: Set 1 . Storage for 5 days at $55^{\circ} \mathrm{C}$

Set 2. Storage for 6 days at $55^{\circ} \mathrm{C}$

Set 3. Storage for 3 days at $55^{\circ} \mathrm{C}$

Each set had two coded samples and one control sample marked $\mathrm{R}$ that was similar to one of the coded samples. One of the coded samples was the fresh sample (which had been frozen) while the other was the stored sample. The panelists were required to identify the coded sample which was different from $\mathrm{R}$. The data was analyzed using a One-Tailed Binomial Test for significance, with a two-sample Statistical Chart for Difference.

The sample that was scored highest by the panelists, but also was cheap and scored highly in nutrition was used in shelf-life analyses. Its nutritional composition after storage was also analysed.

\subsection{Experimental Design}

The experimental design was Complete Randomized Design (CRD) using five treatments (samples) and 15 panelists. The experiment had three replicates. Analysis of variance was performed on the data using the general linear model procedure of statistical analysis, using GENSTAT Statistical Package) [12] and multiple comparisons among means was done using Duncan's Multiple Range Test, LSD at 5\% level of significance [13].

\section{Results}

The average cooking time was $19.5 \mathrm{~min} \pm 0.35$. The levels of $\mathrm{pH}$, vitamins, titratable acidity, which was measured as Malic acid and ${ }^{\circ}$ Brix available in the mango puree, the raw sweetpotato roots and in the boiled sweetpotato roots are summarized in Table 2 . The levels of $\mathrm{pH},{ }^{\circ} \mathrm{Brix}$, total solids and vitamins available in the different samples is outlined in Table 3.

\subsection{Effects of Pasteurization on the Nutrients}

The losses of beta-carotene were between $17 \%$ and $21 \%$. Ascorbic acid losses were between $18 \%$ and $28 \%$. Total solids increased by $3 \%$ on average. The nutritional composition of the samples after pasteurization is shown in Table 4.

\subsection{Sensory Results}

Figure 2 shows the sensory results for appearance, colour, flavor, texture and overall acceptability for the five samples from a seven point hedonic rating scale.

\subsection{Storage Results}

\section{Duo-Trio Test Results}

These were results of Sample number 2. The Statistical Chart for 14 panelists in a two sample difference test, gave 12 correct judgment as significant at the $1 \%$ 
Table 2. Nutritional Composition of mango, raw sweetpotato and boiled sweetpotato.

\begin{tabular}{cccc}
\hline & Mango Puree & Sweetpotato (Raw) & Sweetpotato (Boiled) \\
\hline $\mathrm{pH}$ & $3.9 \pm 0.1$ & - & $5.6 \pm 0.0$ \\
$\begin{array}{c}\text { Beta-carotene } \\
(\mathrm{mg} / 100)\end{array}$ & $0.38 \pm 0.30$ & $5.65 \pm 0.15$ & $4.28 \pm 0.12$ \\
$\begin{array}{c}\text { Ascorbic Acid } \\
(\mathrm{mg} / 100 \mathrm{~g})\end{array}$ & $67.2 \pm 0.42$ & $21 \pm 0.14$ & $16 \pm 0.16$ \\
$\begin{array}{c}\text { Titratable Acidity } \\
(\text { as Malic Acid })\end{array}$ & $0.89 \pm 0.25$ & - & - \\
Total Solids \% & $18.4 \pm 0.17$ & $27.5 \pm 0.28$ & $26.5 \pm 0.3$ \\
${ }^{\circ}$ Brix & $13.5 \pm 0.5$ & - & $7.5 \pm 0.15$ \\
\hline
\end{tabular}

${ }^{\mathrm{a}}$ Mean \pm Standard Deviation $(\mathrm{N}=3)$.

Table 3. Nutritional composition of the samples for baby food formulation.

\begin{tabular}{ccccccc}
\hline Samples & $\mathrm{pH}$ & ${ }^{\circ}$ Brix & $\begin{array}{c}\text { Total } \\
\text { Solids }(\%)\end{array}$ & $\begin{array}{c}\text { Ascorbic acid } \\
(\mathrm{mg} / 100 \mathrm{~g})\end{array}$ & $\begin{array}{c}\text { Beta-carotene } \\
(\mathrm{mg} / 100 \mathrm{~g})\end{array}$ & $\begin{array}{c}\text { Retinol Equivalent } \\
(\mu \mathrm{g} / 100 \mathrm{~g})\end{array}$ \\
\hline 1 & 4.5 & 14.5 & 25.6 & 16.5 & 2.61 & 435 \\
2 & 4.3 & 14.0 & 24.8 & 22.3 & 2.36 & 393 \\
3 & 4.2 & 13.0 & 24.0 & 27.7 & 2.11 & 352 \\
4 & 4.1 & 12.5 & 23.3 & 33.4 & 1.86 & 310 \\
5 & 4.0 & 12.5 & 22.5 & 39.0 & 1.63 & 271 \\
\hline
\end{tabular}

Conversion factor $=6 \mu \mathrm{g}$ beta-carotene $=1$ retinol equivalent. Biological activity of beta-carotene is $50 \%$ that of retinol, while its digestibility is $33 \%$ that of retinol. Bio-availability of pure beta-carotene is $16.7 \%$.

Table 4. Nutritional composition of different samples after pasteurization.

\begin{tabular}{ccccc}
\hline Samples & Total Solids (\%) & $\begin{array}{c}\text { Ascorbic acid } \\
(\mathrm{mg} / 100 \mathrm{~g})\end{array}$ & $\begin{array}{c}\text { Beta-carotene } \\
(\mathrm{mg} / 100 \mathrm{~g})\end{array}$ & $\begin{array}{c}\text { Retinol Equivalent } \\
(\mu \mathrm{g} / 100 \mathrm{~g})\end{array}$ \\
\hline 1 & 26.4 & 11.9 & 2.06 & 343 \\
2 & 25.1 & 16.7 & 1.89 & 314 \\
3 & 24.5 & 21.3 & 1.71 & 285 \\
4 & 24.0 & 26.7 & 1.53 & 254 \\
5 & 23.2 & 32.0 & 1.35 & 225 \\
\hline
\end{tabular}

level (highly significant), while 10 and below were not significant, even at 5\% level (The minimum significant number of correct responses for 14 panelists is $11)$.

The conclusion is that the changes due to storage of the product at $25^{\circ} \mathrm{C}$ could be detected by sensory analysis after six months of storage ( 6 days at $55^{\circ} \mathrm{C}$ ), but not after five months or below.

\subsection{Effects of Storage on the Nutrients}

Ascorbic acid decreased by $45 \%$ (of the remaining content). Beta-carotene decreased by $18 \%$ (of the remaining content). The recommended retinol equivalent 


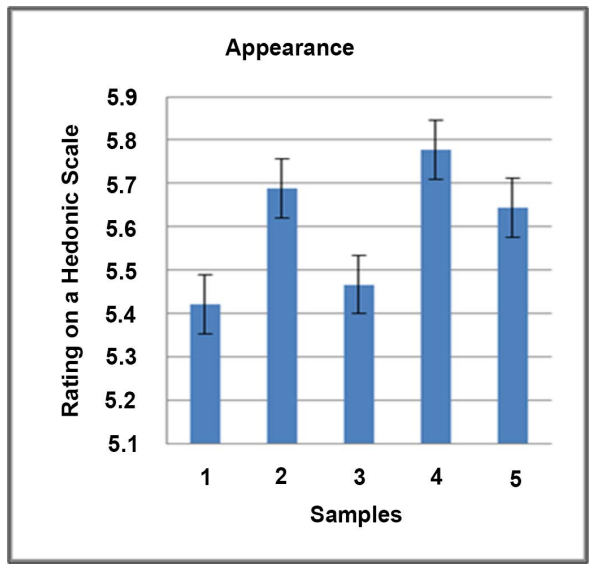

(a)

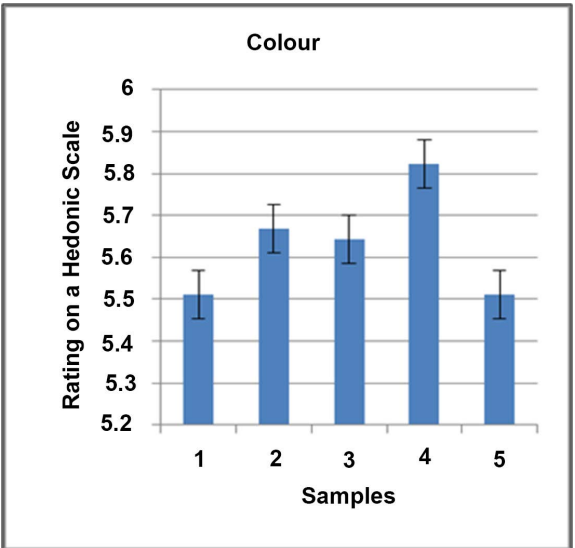

(b)

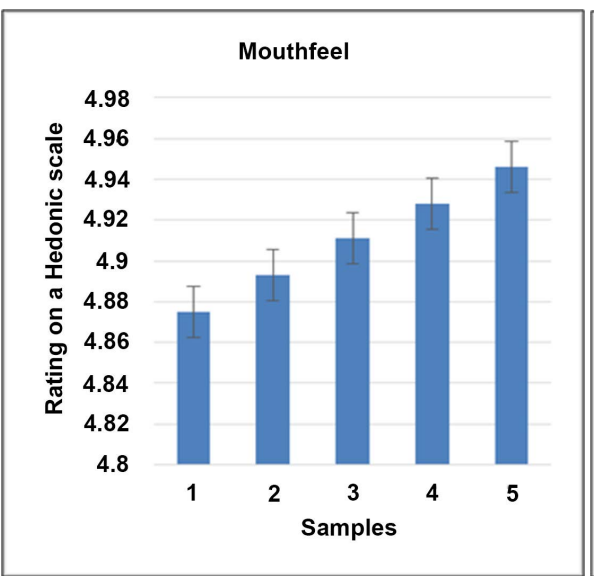

(d)

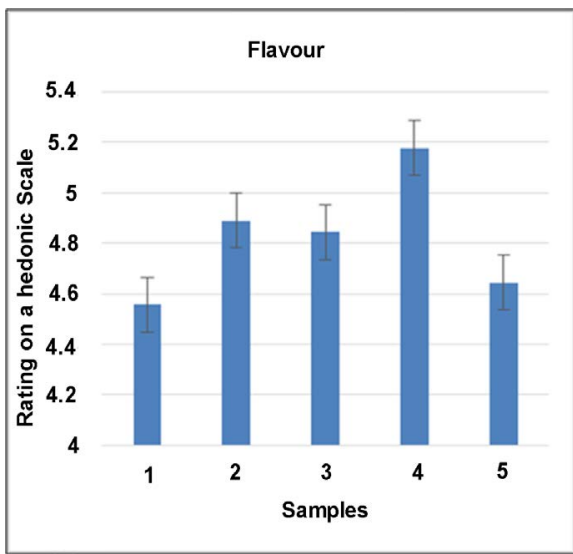

(c)

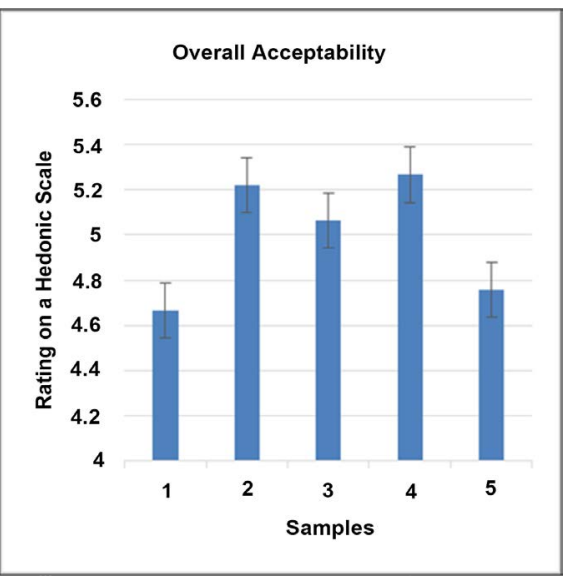

(e)

Figure 2. Sensory results showing rating for different samples.

for infants and $1-10$ year old infants are $350 \mu \mathrm{g}$ and $400 \mu \mathrm{g}$ per day respectively [14]. Therefore, the final stored product could provide $73.7 \%$ and $64.5 \%$ of retinol equivalent for the above two groups respectively. It could also provide $48.88 \%$ ascorbic acid for children 1 - 10 years old [14] [15]. The levels of the nutrients in the stored Sample 2 are given in Table 5. 
Table 5. Analysis of the stored product.

\begin{tabular}{cccccccccc}
\hline Sample & $\begin{array}{c}\text { Total } \\
\text { Solids }(\%)\end{array}$ & $\begin{array}{c}\text { Ascorbic acid } \\
(\mathrm{mg} / 100 \mathrm{~g})\end{array}$ & $\begin{array}{c}\text { Beta-carotene } \\
(\mathrm{mg} / 100 \mathrm{~g})\end{array}$ & $\begin{array}{c}\text { Retinol } \\
\text { Equivalent } \\
(\mu \mathrm{g} / 100 \mathrm{~g})\end{array}$ & ${ }^{\circ}$ Brix & $\begin{array}{c}\text { Crude } \\
\text { Protein }\end{array}$ & Ash & $\begin{array}{c}\text { Crude } \\
\text { Fiber }\end{array}$ & $\mathrm{pH}$ \\
\hline 2 & 24.8 & 9.2 & 1.55 & 258 & 15 & 1.5 & 0.9 & 2.7 & 4.1 \\
\hline
\end{tabular}

\section{Discussion}

The average cooking time of $19.5 \mathrm{~min}+0.35$ was slightly higher than the reported cooking time of $15.5-18.7 \mathrm{~min}$ of three local cultivars [16]. This could probably be due to the fact that, the slices were being cooked for blending into puree which required softer texture than that required for direct consumption. The water used for boiling the slices was retained to avoid great losses of leached nutrients especially vitamin $\mathrm{C}$.

The beta-carotene level of $5.652 \mathrm{mg} / 100 \mathrm{~g}$ for the fresh sweetpotato roots falls within reported ranges of $1.8-16 \mathrm{mg} / 100 \mathrm{~g}$ for orange fleshed lines [17]. The ascorbic acid level of $21 \mathrm{mg} / 100 \mathrm{~g}$ falls within given ranges of $19.8-32.9 \mathrm{mg} / 100$ $\mathrm{g}$ fresh weight [18]. Reported ranges for the cooked cultivars are $0-20 \mathrm{mg} / 100 \mathrm{~g}$ for beta-carotene [19] and in this case were $4.28 \mathrm{mg} / 100 \mathrm{~g}$, which also falls within reported ranges.

The beta-carotene level of $0.38 \mathrm{mg} / 100$ and ascorbic acid level of $67.2 \mathrm{mg} / 100$ $\mathrm{g}$ in the mango pulp falls within reported ranges for mangoes of $0.35-13$ $\mathrm{mg} / 100 \mathrm{~g}$ for beta-carotene and $0-160 \mathrm{mg} / 100 \mathrm{~g}$ for ascorbic acid respectively [20]. On boiling the sweetpotato roots, the percentage beta-carotene losses were $22 \%$ while vitamin C losses were $33.3 \%$. Reported losses due to boiling peeled and cut-up roots cooked for $20 \mathrm{~min}$ are $20 \%$ - 25\% for carotenoids and 18\% $78 \%$ for ascorbic acid [21]. Boiled sweetpotato can provide $85 \%$ ascorbic acid recommended for 1 - 9 year old children. The losses of beta-carotene and ascorbic acid and the increase in total solids after pasteurization were within reported ranges by earlier investigators [22] [23].

There was no significant difference (at $P=0.05$ ) between the samples in appearance, colour and texture. Sample 4 was significantly different $(P=0.03)$ from sample 1 and 5 in flavor and was highly significantly different $(P=0.002)$ from sample 1 and 5 in overall acceptability. Samples 2, 3 and 4 were not significantly different in all the sensory attributes tested, though sample 4 had the highest scores. Considering the benefits of the product, sample 2 (80\% sweetpotato and 20\% mango) was chosen as the most acceptable. The reasons were:

One, to maximize beta-carotene. Sample 2 had $314 \mu \mathrm{g} / 100 \mathrm{~g}$ retinol equivalent. The highest among the three samples. Second, to minimize cost. The cost of mangoes was Kshs. $40 / \mathrm{kg}$ while the cost of the sweetpotato was Kshs. $25 / \mathrm{kg}$. Therefore, sample 2 was stored for shelf life analysis. Sample 2 can provide $89.7 \%$ of the Recommended Daily Allowance of beta-carotene for infants and $78.5 \%$ for children aged $1-10$ years. It can also provide $88.7 \%$ of RDA of ascorbic acid for 1 - 10 year old children. 


\section{Conclusions and Recommendation}

The baby food was acceptable to the panelists for all the samples, with a minimum of 4.67 scores (Sample 1) and a maximum of 5.27 scores (Sample 4) on a 7-scale Hedonic scale. Apart from the flavor and overall acceptability, the other attributes were not significantly different among the samples.

The product could store without any significant difference (in sensory attributes) from the fresh product for 5 months. After which there was a significant difference at 5\% level in flavor, colour and texture (mouthfeel).

The bottles used for packaging were clear and had a capacity of $300 \mathrm{ml}$. It is recommended that the packaging be done in opaque bottles to avoid exposure to light and the bottles be of different sizes. This would provide a choice for the consumers on the amount of the product one requires. Pasteurization should be done in a pasteurizer with a lid to reduce nutrient losses due to exposure to oxygen during pasteurization. In this project, the pasteurization was carried out in an improvised open pasteurizer. The rest of the micro-nutrients contained in the product should also be determined so as to ascertain the total contribution of the product nutrition-wise. A study should be carried out on children to determine the effectiveness of the product in alleviating VAD.

The baby food (a soft half-liquid mass) should be consumed in amounts of $100 \mathrm{~g}$ per day by scooping from the bottles. It should be used as a between-meal snack.

\section{Acknowledgements}

We acknowledge the assistance given by the University of Nairobi, Faculty of Agriculture Field Station for providing the orange fleshed sweetpotato for free, for the project.

\section{References}

[1] WHO (World Health Organization) (1995) Global Prevalence of Vitamin A Deficiency. Micronutrient Deficiency Information System. WHO MDIS Working Paper \# 2. WHO, Geneva.

[2] FAO/ILSI (Food Agriculture Organization of the United Nations/International Life Sciences Institute) (1997) Preventing Micronutrient Malnutrition: A Guide to Food-Based Approaches. A Manual for Policy Makers and Programme Players, Washington, DC.

[3] Ngare, D.K., Muttunga, J.N. and Njonge, E. (2000) Vitamin A Deficiency in Pre-School Children in Kenya. The East African Medical Journal, 77, 421-424.

[4] UNICEF (1990) Strategy for Improved Nutrition of Children and Women in Developing Countries. A UNICEF Policy Review, UNICEF New York.

[5] FAO (1989) Utilization of Tropical Foods: Roots and Tubers. FAO Food and Nutrition Paper, 47/2.

[6] Truong, V.D. and Fementira, G.B. (1990) Formulation, Consumer Acceptability and Nutrient Content on Non-alcoholic Beverage from Sweetpotato. In: Product Development for Root and Tuber Crops: Changing Role in a Modern World. Proc. 8 th Symposium of the International Society for Tropical Root Crops, Bangkok, 
Thailand, 389-399.

[7] Ranganna, S. (1977) Manual of Analysis of Fruits and Vegetable Products. Tata-McGraw-Hill Publishing Company, Ltd. New Delhi, India.

[8] Lees, R. (1975) Food Analysis: Analytical and Quality Control Methods for the Food Manufacturer and Buyer. Leonard Hill Books, London, UK

[9] IFFJP (1984) International Federation of Fruit Juice Producers Method. Analysen-analyses, Fruit-Union Suisse Assoc. Svizzera Frutta, Zug, Switzerland.

[10] AOAC (2000) Official Methods of Analysis of AOAC International. 17th Edition, Vol. 1. AOAC Int, Gaithersburg, MD.

[11] Pearson, D. (1976) The Chemical Analysis of Foods. 7th Edition, The Avi Publishing Company, Connecticut.

[12] Lane, P. and Payne, R.W. (1996) Genstat for Windows ${ }^{\mathrm{TM}}$ Introductory Course. $2^{\text {nd }}$ Lawes Agricultural Trust. Rothamsted Experimental Station.

[13] Steel, R.G.D. and Torrie, J.H. (1980) Duncan's New Multiple Range Test. In: Principles and Procedures of Statistics, McGraw-Hill, New York, 187-188.

[14] FAO (1988) Requirements of Vitamin A, Iron, Folate and Vitamin B12. Report of a Joint FAO, WHO Expert Consultation, Geneva.

[15] Haytowitz, D.B. and Matthews, R.H. (1984) Composition of Foods. Vegetables and Vegetable Products, Human Nutrition Information Series. USDA Agriculture Handbook No. 8, Washington DC.

[16] Ojijo, N.K. (1991) Objective Evaluation of Quality Changes in Stored Sweetpotatoes. M.Sc. Thesis, University of Nairobi, Nairobi.

[17] Woolfe, J. (1992) Sweetpotato-A Versatile and Nutritious Food for All. In: Scott, G.J., Ferguson, P.I. and Herrera, J.E., Eds., Product Development for Root and Tuber Crops, International Institute for Tropical Agriculture, Ibadan, 91-102.

[18] Bradbury, J.H. and Singh, U. (1986) Ascorbic and Dehydroascorbic Acid Content of Tropical Root Crops from the South Pacific. Journal of Food Science, 51, 975-978. https://doi.org/10.1111/j.1365-2621.1986.tb11212.x

[19] Woolfe, J.A. (1992) Sweetpotato: An Untapped Food Resource. Cambridge University Press, New York.

[20] Manthey, J.A. and Perkins-Veazie, P. (2009) Influences of Harvest Date and location on the Levels of Beta carotene, Ascorbic Acid, Total Phenols, the in-vitro Anti-oxidant Capacity and Phenolic Profiles of Five Commercial Varieties of Mango (Mangifera indica L.). Journal of Agricultural and Food Chemistry, 57, 10825-10830. https://doi.org/10.1021/jf902606h

[21] Watson, J.D. (1976) Ascorbic Acid Content of Plant Foods in Ghana and the Effects of Cooking and Storage on Vitamin Content. Ecology of Food and Nutrition, 4, 207-213. https://doi.org/10.1080/03670244.1976.9990430

[22] Dietz, J.M. and Gould, W.A. (1986) Effects of Process Stage and Storage on Retention of Beta-Carotene in Tomato Juice. Journal of Food Science, 51, 847-848. https://doi.org/10.1111/j.1365-2621.1986.tb13951.x

[23] Trammell, D.J., Dalsis, D.E. and Malone C.T. (1986) Effect of Oxygen on Taste, Ascorbic Acid Loss and Browning for HTST-Pasteurized, Single-Strength Orange Juice. Journal of Food Science, 51, 1021-1023. https://doi.org/10.1111/j.1365-2621.1986.tb11223.x 